\title{
A Study on the Problems of College Translation Teaching for Non-English Majors in China
}

\author{
Xie Zhang ${ }^{1}$, Huanqi Ji ${ }^{2}$ \\ ${ }^{1,2}$ College of Humanities, Sichuan Agricultural University, Ya'an 62500, China \\ becky0919@126.com,joe0919@126.com
}

\begin{abstract}
The current problems of translation teaching for non-English majors in Chinese colleges and universities are probed in three aspects. They include discussions on College English Curriculum Requirements (2007), Chinese translation teaching mode and students' motivation in attending translation classes. Tentative solutions are proposed for the problems of college translation teaching in China.
\end{abstract}

Keywords: College Translation Teaching, Non-English Majors, Problems

\section{Introduction}

Almost all the Chinese English teachers have long thought that enhancing college students' translation ability is an important part for the overall English teaching curricula in China. Translation teaching is not only reflective of college students' basic English skills, but also is an important means to improve their comprehensive ability to use English language. Thus, translation for the Chinese college students is highly practical and useful. Nevertheless, the translation abilities of college English students in China are, on the whole, at such a low level that is far from satisfying. Several factors are thought to contribute to the current problems in translation teaching in Chinese colleges: first, the impractical College English Curriculum Requirements; second, the negligence of translation teaching in Chinese college English classes; third, the lack of translation course book; fourth, the disinterest of students' in learning translation. Therefore, this paper is intended to explore all those above-mentioned four factors and seek to think of solutions to improving the Chinese college students' translation ability.

\section{Literature Review}

Chinese English classes have long been neglecting translation teaching since 1980s though greater importance has been attached to the translation teaching for those Chinese English majors. This can be considered to be the fundamental reason why current Chinese college students have such a lower ability in translation. Mu Lei points out that translation teaching in China mainly focuses on teaching Chinese English majors and students who intend to earn a degree of Master of Translation and Interpretation (shortened as MTI) [1]. It can clearly be seen that translation teaching for the general Chinese college students is totally neglected, but the fact is that over 90 percent of registered Chinese college students are neither English majors nor those trying to get a degree of MTI. Xu Jianping comments that judging from the test result of College English Test (band 4), over 80 percent of the students are lacking in a proper skill of translation. $\mathrm{Xu}$ suggests that it is high time that translation teaching 
classes should be included in college English curriculum. [2] In order to eliminate the bias against translation teaching in Chinese English classes, Luo Xuanming suggests that translation teaching classes in China should consist of those for the English majors and those for the non-English majors, and equal importance should be given to the latter. [3] Under the new domestic and international circumstances, Cai Jigang proposes "stress translation teaching in Chinese college English classes and improve students' practical ability of English". Cai thinks that translation teaching has not be stressed enough either in the curriculum or College English Test in China. [4] Li Zhonghua thinks that translation teaching in Chinese college English classes has been marginalized while comparing the four national English Teaching Syllabuses issued in 1985, 1986, 1999 and 2004. And Li holds similar view that translation teaching has long been neglected. [5]

\section{Problems in Translation Teaching in Chinese College English Classes}

\subsection{The Impractical College English Curriculum Requirements (2007)}

Contrary to the marginalization of translation teaching in Chinese college English classes by the four national English Teaching Syllabuses, the current College English Curriculum Requirements (2007) sets impractical requirements on the translation ability for the students. There are three required levels which consist of ordinary level, relatively high level and higher level. The ordinary level is the basic requirement that non-English majors in Chinese college are supposed to meet, but it defines "translation ability" as follows:

Assisted by dictionaries, students shall be able to undertake the translation of articles with familiar topics either from English to Chinese or Chinese to English, the former of which are to be 300 English words per hour and the latter 250 Chinese characters. Their translated text shall be basically correct without major mistakes in understanding or expressing. [7]

Nevertheless, the Chinese College Teaching Syllabus for English Majors defines "translation ability" in Test for Chinese English Majors (Band 8) just as follows:

English majors shall be able to apply translation theories and techniques to practice and translate into Chinese English articles from British or American newspapers and journals or put into English Chinese essays and ordinary literary works from Chinese newspapers and journals. The English majors shall be able to translate 250 to 300 words per hour and the translated text shall be faithful to the source language text, and is basically correct without major mistakes in understanding or expressing. [8]

As a matter of fact, there are usually four semesters during which English courses are offered for those non-English majors and 4 English classes are available each week. As the English classes are undergoing a continuous reduction nationwide, it is, therefore, both unfeasible and impractical to require those non-English majors to meet a similar translation standard like English majors, who have English lessons every day, within a short space of 2 years.

\subsection{The Ineffective Translation Teaching in Classes}

There are three major Chinese presses which offer English textbooks for 
non-English majors: Higher Education Press, Foreign Language Teaching and Research Press and Shanghai Foreign Language Teaching Press. Although the English textbooks published by the three presses all assign translation exercises, it is regrettable to notice that most of them are just like making sentences rather than translating them. At the same time, few of the Chinese English teachers would like to teach translation skills in the classes, still less translation theories. The reason can be either that Chinese English teachers do not know much about translation skills and/or translation theories or teachers are pressed for time of going through with their teaching tasks in classes. Teachers may just mention some of the translation skills or theories rather than go into details even if teachers sometimes do have time.

On the other hand, translation courses are sometimes set in colleges in China, whereas almost 90 percent of them are just selective ones, which can offer only a short period of teaching translation skills and theories. Take the university the authors work in for example. There are three campuses located in Ya'an, Chengdu and Dujiangyan, three cities of Sichuan province in China, but only Ya'an campus offers a selective translation course with 2 classes each week, which totals 30 classes. Over 150 students usually sign up for such a course but they do not have a right textbook available in class. As translation stresses practical ability in conversion between languages, it is almost impossible to improve each student's translation skills.

\subsection{The Students' Improper Motivation for Translation}

Chinese college students are usually holding a wrong idea that translation simply involves a conversion between two languages and it is easy to translate a source language text only with the help of a dictionary. For one thing, students will place less stress on translation practice as they think words in translation are easy to reproduce in the target language for the simple reason that their meanings are available and set in the dictionary. Or they may have the equally wrong idea that as long as their vocabulary is large enough, they think it unnecessary to learn about translation skills and theories, which, in some students' eyes, even seem to be useless. Just as Liu Miqing commented, "Almost all the dictionaries just record the clear and restricted side of each word, hence indicating a false idea that the meaning of words is similarly clear and restricted." [8] However, such a fact is far from true when a source language text is being translated, because the meaning of words can definitely not be so easy to find in dictionaries as J. R. Firth once said, each word when used in a new context is a new word. It is this inability on the part of the students to interpret through context in translation that prevents them from taking a strong interest in learning translation skills or theories as well as doing a good job in translation.

Nevertheless, there are more than meets the eyes. For those non-English students who actually sign up for a translation class, their motivations to learn translation are also doubtful. As mentioned above, translation courses for non-English majors in Chinese colleges or universities are usually selective rather than compulsory. In the eyes of Chinese college students, they tend to think selective courses are naturally less important than compulsory ones, thus making them take a less serious attitude toward translation courses. Some of them may just intend to earn the required credits instead of truly trying to improve their translation abilities. Moreover, class attendance for 
selective courses is obviously lower than the seemingly more important compulsory ones. It is definitely not easy both for teachers and students to complete the translation tasks in class, and improving students translation abilities will be out of the question.

Although Chinese College students will have their translation skills examined in the current College English Test (band 4 and band 6), their motivations in learning and doing translation are simply to pass the College English Test band 4 or band 6, earning a certificate of which is usually one of the too many musts for them to obtain their degrees upon graduation, hence, in some students words, relieving them of a serious burden. To make matter worse, for those non-English majors who pass the College English Test band 4 or band 6, they are likely to stop doing English translation or learning English at all. They will usually pick up their English again when required in find a job or taking the national admission tests for postgraduate candidates.

\section{Conclusions}

Now that the non-English majors in Chinese colleges and universities appear to be less motivated not only in improving their translation skills but also in improving their English competence as well, it is high time to remove the current marginalized status of translation teaching for the Chinese non-English majors. This requires eliminating the concept of strictly differentiating translation teaching for English majors and non-English majors. Meanwhile, as there are over 2000 colleges and universities in China, a more practical syllabus shall be compiled so that colleges and universities of different regions can adjust to formulate their own teaching syllabus according to their own students' needs. Lastly, translation teaching shall center on students' cognitive strategy rather than the traditional class mode dominated by teachers, and focuses on improving students' ability of think creatively and express appropriately.

\section{Acknowledgements}

This research work was supported by the General Project of Humanity and Social Science Sponsored by Ministry of Education of China under Grant No. $15 \mathrm{YJC} 740043$.

\section{References}

[1] Mu Lei. Translation Teaching Research in China [M]. Shanghai: Shanghai Foreign Language Education Press, 1999.

[2] Xu Jianping. On the Students' Translation Deficiency from College English Test (Band 4) [J]. Chinese Translators Journal, 2000.

[3] Luo Xuanmin. Reflection and Outlooks on Chinese Translation Teaching [J]. Chinese Translators Journal, 2002.

[4] Cai Jigang. Stress on Translation Teaching and Improvement of Students' English Level [J]. Chinese Translators Journal, 2003.

[5] Li Jianhua. Translation Teaching in China: Status and Countermeasures [J]. Foreign Languages and Their Teaching, 2007.

[6] College English Curriculum Requirements[M]. Shanghai: Shanghai Foreign 
Language Education Press, 2007.

[7] Chinese College Teaching Syllabus for English Majors[M]. Shanghai: Shanghai Foreign Language Education Press, 2008.

[8] Liu Miqing. Translation and Language Phylosophy [M]. Beijing: China Translation Corporation, 2007. 